\title{
Benlik Krizi Bağlamında Modernist Oyun Yazarı Masktan Ne Umdu?
}

\section{What did The Modernist Playwright Expect from The Mask in The Context of The Self-Crisis?}

\section{Banu Ayten Akın}

Doç. Dr., Dokuz Eylül Üniversitesi, Güzel Sanatlar Fakültesi, Sahne Sanatları Bölümü

email: banuaytenakin@hotmail.com (DORCID ID: https://orcid.org/0000-0002-0752-5198

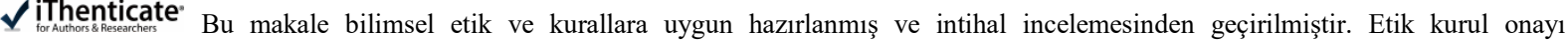 \\ gerektirmemektedir. \\ Atıf (APA 6)/To cite this article \\ Akın, B. A. (2020). Benlik krizi bağlamında modernist oyun yazarı masktan ne umdu?. Atatürk Üniversitesi Güzel Sanatlar Enstitüsü Dergisi, \\ 26(45), 630-638. doi: https://doi.org/10.35247/ataunigsed.767487 \\ Makale Gönderim Tarihi/Received: 10/07/2020 \\ Makale Kabul Tarihi/Accepted: 04/10/2020 \\ Makale Yayın Tarihi/Published: 22/10/2020
}

Review Article/Derleme Makale

$\ddot{O} z$

Modern tiyatroda mask, oluş ile ilgili krizlerin örneklenmesinde kullanılmıștır. Tiyatroda benlik krizi, yüzü başkalaştıran, genel ifadede donduran mask aracılı̆̆ılla farklı amaçlarla, farklı yazarlar tarafından sıklıkla kullanılmışıı. Özneyi yeniden bütüncüllestirmeye çalıșan bir çağda, çağdas yazar somut veya soyut masktan ne ummuştur? Bilindiği gibi dramatik yazarlıkta bir kavram olarak karakter, modern özne biçimlerine derinden bağımlıdır. Aynı zamanda benliğin algısı ve benlik ile dünya arasındaki ilişkilerdeki değişikliğin bir tezahürünü kendinde olușturmaktadır. Benliğin asal krizi yüz/maske kutuplaşmasına dayanır. Batı düşüncesinde maske, her zaman muhalefet anlamına gelir. Maske öznelliğin göstergesi olmasının tersine, esssiz benlik, insan yüzü fikrinin son çaresidir. Maske, gerçek benlik yaratmanın imkânsızlığının bir işareti olsa da altta yatan bir melankoliye ișaret eder. Maske ile belirgin yakınlıkları olan baska bir kavram ise metamorfoz kavramıdır. Kimlik kararsızdır, ancak metamorfoz onun hem kaybı hem de garantiye alınmıs halidir. Metamorfoz anı, hem kendinden önce hem de sonraki anları içine alır. Paradoksal olarak, kimlik istikrarsızlaşırken bile kendisinin hayatta kalmasını sağlar. Bu çalıșma Pirandello, Brecht, Genet ve Müller örnekleminde maske ve metamorfozun modern oyun yazınındaki yerini inceler.

Anahtar kelimeler: Maske, Metamorfoz, Benlik, Modern, Postmodern, Tiyatro

\begin{abstract}
In modern theater, the mask was used to sample crises related to occurrence. The self-crisis in theater has been used through a mask that transforms and freezes the face in general expression, for different purposes by different authors. In an age of trying to reintegrate the subject, what did the contemporary writer expect from a physical or abstract mask? As is known, as a concept in dramatic writing, character is deeply dependent on modern forms of subjects. The character also constitutes a manifestation of the self's perception and the change in the relations between the self and the world. The basic crisis of the self is based on face/mask polarization. The mask always means opposition in the western world thought. The mask is always the unique self, the last resort of the idea of the human face. The mask refers to melancholy, although it is a sign of the impossibility of creating a true self. Another concept is metamorphosis which has to do with the mask. Identity is unstable, but metamorphosis is both its loss and guarantee. Metamorphosis involves the moment before and after it. Paradoxically, identity allows its survival even when it becomes unstable. This study examines the role of masks and metamorphosis in modern dramatic literature in Pirandello, Brecht, Genet and Müller.
\end{abstract}

Keywords: Mask, Metamorphosis, Self, Modern, Postmodern, Theatre

\section{Giriş}

Anton Çehov'un Martı'sında (1895) Nina, Treplev'in yazdığı oyunun oynanmasının zor olduğundan dem vurmaktadır. Ona göre bu karakterler canlı değildir ve adeta hiç yaşamamaktadır. Treplev'in yanıtı şu olur: "Canlı kişiler! Hayatı olduğu ya da olması gerektiği gibi değil, hayalimizde canlandırdığımız gibi betimlemek gerekir" (Çehov, 1995, s. 101). Sonraki süreçte Nina'nın bir oyuncu olarak karaktere motivasyon ve eylem, duygusal nedensellik ve psikolojik determinizm açısından tutarlılık sağlama arzusu gittikçe uzaklaşılan bir hayal olacak ve hayatının ve zamanının açmazları içinde bu, daha az sorun haline gelecektir. Görülen o ki; geçmişe meydan okuyan modernist yazar, artık sadece hayallere ve rüyalara tutunarak karakter yaratmak istemektedir. Bu esnada zihin içinde somut dünyadan uzak üretilmiş karakterler yavaş yavaş sahneyi işgal edecek, yaşamları bedbaht olmuş nice Treplevler zafer kazanacaktır. Ondokuzuncu yüzyıl gerçekçi kanyonun çıkmazından avangart ruhun arayışlarına geçiş başlamıştır. 19. yüzyılın sonunda da Ortaçağ Hıristiyan mystery'lerinin yaradılış, düşüş, acı çekme, kıyamet döngüsüne tutunan irrasyonalistlerin (absürdistlerden postmodernistlere) karakterin iradesinden ya da irade niyetinden kurtardıkları bir dramaturgiye doğru yol aldıkları aşikardır. Shakespeare ile birlikte başlayan ve modern dramaturgide takındığı değișken psikolojik hallerle karakter, belli ruh hallerinin ya da tutkuların maskesi haline gelerek ilk olarak sembolistlerin dünyasından kovulacaktır. Böylelikle avangartların arayışına anti-karakter, erimiş, parçalanmış ya da yok karakter olarak giriverirler. 
Elinor Fuchs'un (1933-...) Karakterin Ölümü'nde sorunu Aristoteles'in (384-322) Poetika'sından başlatıp Nietzche'nin (1844-1900) Tragedyanın Doğuşu'nda Sophocles'in ve takipçisi Euripides tiyatrosunun değillemesine götürdüğü bireyleşme sorunuyla ilerletmesi estetik açıdan takip edilmesi gereken zorunlu bir süreçtir. Ne de olsa eylemden sonraya yerleştirdiği karakter ile Aristoteles, kendisi üzerine modern tartışmalarla Aristotelesçi olmayan tiyatroya da kılavuzluk etmiştir. Hatta Nietzche, Sophocles'in tiyatrosunun "burjuva tiyatrosuna doğru ölümüne sıçrayış" yaparak öznenin süreksiz, keyfi doğasıyla birey olma yanılsaması içinde insanı teslimiyet kökeninden kopardığını söyler (Fuchs, 2003, s. 48).

Biri, Hiçbiri, Binlercesi romanındaki Moscardo karakteriyle "Bir dakika önce...başka biriydiniz, hatta yalnızca bir değil yüz, hatta yüzbin başka kişiydiniz” diyen Pirandello (2015, s. 50), oyunlarında da karakterlerinden bunu talep eder: yok ve var, hep ve hiç, kendi görünüş ve oluşunun dışında da olmaya devam etmek, kendini görmemek, görünmek. Gerçekte olduğumuz ve olduğunu sandığımız insan aynı değildir ona göre. Bizler, hepimiz, bir kişiyiz, hiçbir kişiyiz, yüzbinlerce kişiyizdir. Maskeler takarız, bazen binlerce. Bu maske kalıbının altında (ister bir yüz kalıbı, ister bir persona olarak) gerçeğe değinen acı bir gerçek vardır. Bu nedenle Pirandello, kendi tiyatro edebiyatında görünüş ile oluşu karşı karşıya diker ve onlardan birbirlerine anlaşmazlığın dehlizlerini göstermelerini talep eder.

Modern tiyatroda mask, oluş ile ilgili krizlerin örneklenmesinde kullanılmıştır. Tiyatroda kendilik/benlik krizi, yüzü başkalaştıran, genel bir/çok ifadede donduran mask aracılığıyla farklı amaçlarla, farklı yazarlar tarafından sıklıkla kullanılmıştır. Genet (2000), Hizmetçiler'in karakter değişimlerini görünmez bir rol maskesi altına gizler. Özne metamorfoz olgusu altında adeta bir maskeye indirgenmektedir. Solange Claire olur, Claire Solange. Aynı hizmetçi kıyafetleri, boneleri ve tavırları birbirlerinin aynadaki görüntüleri olmalarına yeter de artar. Onlar hizmet edenlerden fazlası değildir. Sezuan 'ın İyi İnsanı'nda Brecht, Shui Ta'ya maske taktırır, sistemin dayattı̆̆ı iyi ve kötü oluşu, birbiriyle savaşmayacak biçimde ayırır. Genet (2014), Zenciler'de, siyah seyirciye gerekirse beyaz mask takmak gerekliliğinden söz eder. Genet (1991), Paravanlar'da çirkin Leyla'nın ağzı dışında tüm suratını siyah bir maskeyle kapatır. Maskenin arkasında izleyene bile gösterilemeyecek kadar çirkin bir hayal vardır (Akın, 2017, s. 68). Hem benliği maskeler, hem başkalaştırır. 20. yüzyılda maske ya da persona benlik krizine bir form olarak kullanılmıştır. Mimus oyunlarından antik tragedyaya, commedia dell'arte'den av köşklerindeki maske oyunlarına kadar pek çok defa sahnede gördüğümüz somut bir form olan maskeyi ve onun 20. yüzyılla birlikte soyutlaşan ve yüze entegre edilen yeni formunun modern kişileştirme yorumlarıyla ilgisi olduğu açıktır. Öyleyse incelemedeki soru şu olacaktır: Özneyi yeniden bütüncülleştirmeye çalışan beyhude çabaların kol gezdiği bir çağda, çağdaş yazar somut veya soyut masktan ne ummuştur?

Bilindiği gibi dramatik yazarlıkta bir kavram olarak karakter, modern özne biçimlerine derinden bağımlıdır ve aynı zamanda benliğin algısı ve benlik ile dünya arasındaki ilişkilerdeki değişikliğin bir tezahürünü kendinde oluşturmaktadır. 20. yüzyıl tiyatrosundaki teatrallik projelerinin önemli yönlerinden biri de kimlik ile alterite, benlik ve öteki arasındaki ilişkilerin araştırılmasıdır. Felsefi, psikolojik ve sosyolojik benlik ve özne düşünmelerinin yansıması kaçınılmaz olarak dramatik yazarlıktaki kişileştirmede kendine doğrudan yer bulur.

\section{Yöntem}

Araştırma betimsel modele dayalı nitel bir araştırmadır. Araştırmada literatür taraması yoluyla Pirandello, Brecht, Genet ve Müller örnekleminde maske ve metamorfozun modern oyun yazınındaki yeri incelenmiştir.

\section{Modern Tiyatroda Kişileştirmeyi “Özne ve Benlik” Düzleminde Kavramsallaştırma}

Aydınlanma felsefesinin bir çıktısı ve modernitenin bir sonucu olarak geçtiğimiz yüzyılda benlik ve kimlik kavramları çokça tartışılmıştır. Modern benlik genel ifadeyle, akılla bilinebilir bir dünyanın merkezinde benzersiz, otantik, gerçek, birincil ve istikrarlı bir kimlik olarak tanımlanmıştır. Özgürleştirilirken tektipleştirilerek ve üst bir kurgu içinde “öteki”"nin varlığını görmezden gelerek bireycileşen bu özne, çok geçmeden kendi oluş krizini yaşayacaktır. İnsanın özne olarak kurgusu 17. yüzyıla, kişiliğinin karanlık yönleriyle yüzleşmesi 19. yüzyıla, çıkışsızlığı ve muğlaklığı ile maskeli bir varlık olarak incelenmesi 20. yüzyıla ait görünmektedir.

\section{1. “Düşünüyorum Öyleyse Varım”cı Öznenin İflası}

Felsefi gelişimini takip edecek olursak özne kurgusu; Descartesça kavramsallaştırılan kartezyen cogito ile ilişkilidir. Descartes 17. yüzyılda beden ve zihin ayrımını yaparak, Ortaçağ'ın ayrılmaz bütün diye baktığı beni ayırmayı başarır. Zihin/madde ayrımını ilk anlamlandıran düşünür milat öncesi 5. yüzyılda Platon olmuştur. Platon maddi dünyanın nesnelerinin bu dünyadan bağımsız olan idealar dünyasının kopyaları olduklarını, bu nedenle asıl gerçekliğin idealar dünyası olduğunu, bizi kuşatan maddi dünyanın gerçek olmadığını iddia ederek sorunu ilk gören olmayı başarmıştı. George Berkeley'in "Varolmak algılanmaktır (Esse est percipi)" sözü 18. yüzyıl ontolojik idealizminin özdeyişi haline gelmiştir. Epistemolojik idealizmin temsilcisi Immanuel Kant ise Aydınlanma düşüncesinde usu, siyaset, din ve doğada takip ederek ortaya çıkan şüphecilik ve naturalizmin birbiriyle çelişmesini engellemek ister. Numen (kendinde şey) ve fenomen (görüntü) ayrımını geliştiririr. İnsan olarak biz 
bizatihi kendinde şeyler olduğumuz için, eğer kendimizi tanıyabilirsek, o zaman kendinde şeylerin ne olduklarını bilebiliriz (Kurun, 2018, s. 273-301).

Modern felsefenin başlangıcı olan Descartes'ın öznesi, bir yönüyle dünyaya, bir yönüyle de nesneye karşı konumlanmış, kendi varlığını gerçekleştirmek ve korumak amacıyla savaşan, dünyayı, tasarımından hareketle şekillendirmeyi arzulayan bir öznedir. Bu özne bilginin merkezi, bilincinin ta kendisidir. O, bilinçte sağlam bir zemin bulduktan sonra varlıkla hiçbir diyalojik ilişki ihtiyacı olmaksızın varlığın anlamının keşfedebileceğini savunur. Descartes'a kadar olan dönemde insan anlığı evrenin düzenine bağlı olarak konumlanırken, şimdi artık evrenin düzeni insan anlığına bağlı olarak tanımlanmaya başlanmıştır. Bir iç alan yaratılmıştır, özne orada ikamedir. Heidegger, Descartes'ın "ego" üzerinden öznenin kendini güvenceye alan metafiziğinin, insanı hakikat bağlamında kilisenin aracılığından kurtarma gayesi güderken, bu sefer de "ortak ego"nun tutsaklığına düşürdüğünü ifade eder (Kahraman, 2018, s. 137-138). Modern insan için dünya öteki olmuştur; incelenecek, yorumlanacak, erotikleştirilecek, sergilenecek, sömürgeleştirilecek, arzulanacak, alçaltılacak ve sonuçta öldürülecek bir nesne. Bu sayede ben olmayan tüm varlık istenildiği gibi şekillendirilebilecek, tahakküm altına alınabilecektir. Batı kültürünün, yazı karşısında sözü, kadın karşısında erkeği, siyah karşısında beyazı, şark karşısında garbı öne çıkarmasını gerekçelendirecek hiçbir ölçüt söz konusu değildir. Bir kurgudan ibaret modern insan, ötekinin de kimlik içinde olduğunu unuttuğu bu yolculukta, kimliklerin belirsizleşmesi, öznenin dağılması sonucuna ulaşır.

Aydınlanma felsefi düzlemde insanı özneye dönüştürme çabasıyken öznenin çözülmesini başlatan olmuştur. Dünyayı gizlerinden kurtarmak, mitleri parçalayarak aklın iktidarına almak isteyen Aydınlanma düşüncesi, Heidegger'in dediği gibi bizatihi kendisi hurafeleşecek ve tümelleşecektir. Ben artık ne kendi (özne) ne öteki (nesne)dir (Horkheimer ve Adorno, 2010). Hiç kimse ya da her şey olarak da tanımlanamaz. Yabancıdır, görelidir, tekinsizdir. Postmodernizmde özne olarak bilinen iç alan, artık işin esasını oluşturmamaktadır, özne artık dilde bir işarete bir tertibe indirgenmiştir; özne, yerini işgal eder ama kendisi boşaltılmıştır (Fuchs, 2003, s. 17). Kurtuluş nidasıyla postmodernizm bir güzel eleştirdiği modernizmin açmazından kurtarmak istediği özneyi, kendi sistemsizliğiyle bir boşluğa firlatacaktır. F. Jameson'a (1934-...) göre Einstein'ın rölativizmi bile benlik krizinin yeterli bir tanımını yapmaya yetmez (Fuchs, 2003, s. 16).

\subsection{Benlik Kuramları Çağı}

Öznenin içini dolduran bileşenler olarak duygular, imajlar kültür, din, siyasal iktidarla iletişimi sonrasında kimliği var eder. Öznel bir bütünlük, tutarlılık ve süreklilik oluşumudur kimlik (Aydoğdu, 2004, s. 117-126). Psikanalitik geleneğin kurucusu ve temsilcisi Freud (1856-1939) açısından kimlik, bireyin yabancı kişileri ya da nesneleri özümsemesi, özdeşleşmesi sonucu erken yaşlarda oluşur. Bir psikanalist olarak Freud, kimliği salt cinsellik üzerine kurarken sosyal yapıları ikincilleştirerek bütüncül bir özne teoremi yaratamamıştır. Ardından gelenlerle (Jung, Adler, Horney, sonrasında Ericson) psikolojik açıdan kimlik, sosyolojik yapılarla yeniden anlamlandırılmaya çalışılır. Özellikle Ericson kimlikten ömür boyu edinilen bir süreç olarak söz edecektir. Bu süreci öznenin kaygıll, gerilimli ve pek çok rol ve ideolojileri denediği bir süreç olarak görür.

Yine 20. yüzyılda Galen Strawson'un inci görüşü dediği ve ortak görüşte ego teorisi olarak adlandırılan, bedenin içindeki birey algısı ya da benliğin varlığımızın çekirdeğinde, yaşamımız boyunca bizi sabitleyen bir öz olduğu biçimindeki görüş, aynada bana yansıyan ben görüşüdür. Bunlara tezat bir görüş David Hume tarafından çok daha önce, 18. yüzyılda 'Demet kuramı'nda alternatif bir benlik teorisi olarak çıkmıştı. Hume iç benliğini tanımlamaya çalışırken tek bir benlik olmadığını, tersine birbiri üzerine yığılmış düşünceler, algılar ve duygular demeti olduğunu düşünmüştür. Bu kuram hala kabul gören bir kuramdır. Öte yandan yine 20. yüzyılda F.de Saussare yapılsalcılığından beslenen M. Foucault, kimlik oluşumuna dil ve temsille birlikte söylemi de ön plana çıkartır. Özne ötekini söylemle tanır ve tanımlarken özne deneyimini kurar (Aydoğdu, 2004, s. 122).

Marx tarafından karakter maskesi olarak dayatılan toplumsal ve sistem içi yansıma Jung'un persona olarak sözünü edeceği öğeyi anımsatır. Persona benlik için sosyal maskedir. Maksatlı benimsenen bir tutumu somutlar. Jung, "Persona yalnızca psişik özelliklerle değil, aynı zamanda sosyal davranış biçimleri ve kişisel görüntümüzle ilgili alışkanlıklarla, duruşumuzla, yürüyüşümüzle, giyinme biçimimizle, yüz ifadelerimizle, gülüşümüzdeki anlamla, çattı̆̆ımız kaşımızla, hatta saçımızı tarama biçimimizle de ilgilidir”' der (Jacobi, 2002, s. 47).

Düşünür Hans-Georg Gadamer bugün "Benliğimiz kendine hâkim değil, benliğimizin zaman içindeki tesadüfler ve tarih parçacıkları tarafından belirlenen bir olay olduğunu söylemek mümkün” diyor. Gadamer buradan, "insanın kendisinin farkında olma durumu, tarihin kapalı devresinde bir an belirip sönen bir 1şık gibidir" sonucuna varır. Ötekinin kendisi hakkında bilgisi bir yana kendi bilgisinden yoksun kalan benlik sıkıntı duyar. "Günümüz kapitalizminde karşılaştığımız karakter sorunu budur işte” der Sennett. Ortada bir tarih var, ama insanlarca paylaşılan bir mücadele anlatısı ve dolayısıyla ortak bir kader yok. Bu koşullar altında karakter aşınır; bana ihtiyaç duyan kim var gibi bir bir soru da yanıtsız kalır (Sennett, 2008, s. 154-155). 19 ve 20. yüzyıllar benlik ve kimlik üzerine çokça konuşulan zamanları imler. 


\subsection{Budizmden Kuantuma (Yok) Benlik}

Doğu mistisizmi içinde Batı’nın son yüzyılına ve yapıtlarına damgasını vurmuş Budist teorisi, evrensel maddenin formları olması bakımından insan ve dünya arasında farklılıkları gösterir. Annata ya da "yok benlik" kavramı, Budistlerin tüm insan acılarının hayali bir kalıcılı̆̆ kavramasından doğan sonuçtur. Budizme göre benlik, zihnin olaylarla özdeşleşmesindeki bir yanılsamadır. Benlik fikrine bağlılık, ölüm korkusuna, zorunlu kimlik edinme ve yaşamda kontrol kaybına dayanır. Orijinal benlik eksiktir. Aslında duyguları, düşünceleri, fiziksel duyumları ve fikirleri bir benliğe çeviririz. Budizm, geleneksel ve nihai gerçeklik arasında önemli ve yararlı bir ayrım yapar. Bireysel egonun ve kişiliğin bir yanılsama olduğunu anlar. Bu yanılsamadan kurtulduğu an, işte o an, birey nirvananın saadetini yaşayabilecektir.

Budist felsefesi tarafından dile getirilen benlik kavramı ile kuantum fiziği tarafından ima edilen benlik kavramı arasında tuhaf bir paralellik olduğu söylenebilir. Kuantum fiziğinin maddenin doğası hakkında dalga/parçacık ikiliği ifadesi, atomaltı düzeydeki tüm varlıkların ya katı parçacıklar olarak ya da dalgaların hem dalga hem de parçacık gibi eşzamanlı olarak tanımlanabileceği iddiasıdır. Bir gözlemle kendimizi doğanın süreçlerinde parçalar ve ortaklar olarak görmemizi sağlar. Tamamlayıcılık ilkesi, her bir açıklama yolunun diğerini tamamladığını ancak geleneksel açıklama yöntemlerinin kullanılamayacağını söyler. Belirsizlik ilkesine göre temel gerçeklik belirsizdir ve bir olasılık meselesi, bir şans meselesidir. Birçok dünya teorisi, her birinde kendi özümüzün bir versiyonunu bulabildiğimiz ve geliştirdiği diğer olaylardan farklı olarak bulabildiğimiz sonsuz sayıda dünya olduğunu öne sürer ve bunların hiçbiri kaybolmaz, bugün hep birlikte vardırlar (Zohar, 2019).

\subsection{Yeni Kapitalizmde Benlik ve Yüz}

Geç kapitalizmin ileri tüketim ve emtia kültürü, aynı görüntünün boş reprodüksiyonları ile eşsiz yüz ve altın oran fikrini yıkmıştır. Güzellik pazarı, ticari makyaj ve cerrahi estetik, çoğunlukla kadın yüzlerinin birbirine benzeyen sonsuz tekrarlarıyla 'eşsiz yüz'ün yerini almıştır. Böyle bir zamanda maske tekrar tamamlayıcı olarak yüzü karşılayabilir. Yüzün ve maskenin ikili ilişkisini, maskenin modernizm sırasında sahnede varlığını tanımlayan kimlik ve alterite arasındaki gerilimin ötesine geçmenin bir yolu olabilir.

Bu çalışmanın kapsamında değerlendirilecek olan teatrallik arayışları içindeki yirminci yüzyıl sahnesine gelince, mesnedini benliğin felsefi- psikolojik-sosyolojik-politik-teolojik yorumlarından alan dramatik yazarlığın karakter tasavvuru tüm bunlardan ayrı düşünülemez elbette. Krizi ele alma yolları ve olası cevaplar değişebilir. Bu noktada yirminci yüzyılın benlik krizinin maske ve metamorfoz formunu kullanmadaki etkisi incelenmeye değer. Benlik krizi oyunlarında bir araç olarak kullanılan maske, Pirandello'nın deyimiyle yüze karşıdır ve bu karşıtlık farklı yazarlar için farklı formlar yaratır. Yüz kalıbı olarak maske, sosyal rol olarak maske ve tarihte tekerrür eden antik metamorfoz...

Modernist yazar Antik tragedyada duyguyu, komedyada ise tipleri somutlayan maskı geçtiğimiz yüzyıl gibi karşı gerçekçi ve anti tiyatro deneyimleri yaşanan bir zamanda yeniden keşfetmiş gibidir. Bu keşif, tıpk1 görünenin ardındakini arayış gibi maskı da katmanlarına ayırmayı ve hatta onu soyut bir form olarak görmeyi getirmiştir. Bir kurgu dünyada yaşadığını, sistem ve iktidar tarafından kuşatıldığını düşünen insanoğlu benlikle ilgili tasarımlarında karakteri kuşatan dünyayı algılamak ya da onu bu dünyadan özgürleştirmek yollarını seçer. Doğu mistisizmi içindeki kendine dönme ve ruhu bedensiz algılama özlemi Batı kapitalizmine bir kurtuluş umudu olarak girmiştir. Özellikle Desecartes ile başlayan ve Aydınlanma'nın salt akılla kavramaya çalıştığı dünya algısı çökmüş, bilinçaltı gerçeği aramada daha güçlü bir kılavuz haline gelmiştir. Rüyaların yanı sıra mit ve arketiplerin de görünenin ardını yorumlama girişimleri Freud ve Jung ile birlikte kişiyi çözümleme girişimi olarak psikanalizi devreye sokacaktır. Bundan sonra oyun yazarı psikiyatr ile birlikte çalışacaktır. Benlik ruh, arketip, hayal, iradesiz, genetiğin nihai sonucu, belirsiz, temsil, kurgu gibi onlarca teoriye denk gelebildiği gibi çoğaltılabilir, bölünebilir, aynı anda farklı yerlerde bulunabilir ve sistemle birlikte bir maskeye dönüştürülebilir, tektipleştirilebilir, tektipleştirilip çoğaltılabilir, bir yüz ya da bir imaj olarak kodlanabilir vb. Modernist oyun yazarı tüm bu belirsizliğin içinde karakter yaratma umudu olan yazar olarak söz edilen yüzyıla damgasını vurur ve ne onun için ne de seyir eden için artık hiçbir şey ‘belirli bir açıklamaya sahip’ olamaz. Mask bile...

\section{Pirandello, Brecht ve Genet'nin Masktan Umdukları}

Platon'un idealar dünyası ile gerçeklik dünyası arasındaki ayrım, hareket ve biçim arasındaki çatışmada tekerrür eden Pirandello'nun Altı Kişi Yazarını Arıyor'unun ana temalarından biridir. Başka bir oyunun provası sırasında profesyonel bir kumpanya, tiyatroyu istila eden ve çalışmalarını kesintiye uğratan altı karakterle karşı karşıya kalır. Andaki gerçeklik; biçimin mutlak gerçekliği, yaşam akışının göreli gerçekliğine taban tabana zıttır. Karakterler ise sabit görünmekle birlikte psikolojik rölativizm etkisindedir. Daha önce hiç yazılmamış/çünkü bitirilmemiş bir anlatıdaki bu gaip karakterler, hikayelerini bitirmekle ilgilenmeyen bir yazarın hayal gücünün yaratıkları olarak vardırlar (Nesari, Shahraz, Filinezhad ve Nesarid, 2011).

Karakterler, anlatılarını bitirmek ve hayatlarına belirli bir sanat eserinin düzenini ve tutarlılığını vermek için bir yazar aramaktadır. Aslında alıkonulmak istendikleri yerde (tiyatroda) serbest birakılmayı arzu etmektedirler. 
Onların arzusu, Madam Pace'in genelevindeki toplantının önemli bir sahnesini yeniden canlandırmaktır. Üvey kızıyla cinsel bir ilgi kuran Baba, onun kendi üvey kızı olduğunu anladığında büyük utanç duymuştur. Bu eksik yaratı ailenin üyeleri, yönetmeni, hikayelerini sahnelemeye ikna ederler ve aktörler bireysel olarak sahneleri yorumlamaları için geri çağrılır. Kişilerin her biri asıllarından önemli ölçüde farklıdır ve her birinin kendi baktığı yerden gerçek bir defa daha farklı görünmektedir. Pirandello'ya göre karakterler yaratılmış gerçeklik, hayal gücünün değişmeyen yapıları ve bu nedenle de akışkan doğallıkları ile aktörlerden daha sağlam gerçekler olarak sunulmalıdır. Onları aktörlerden ayırmak için maske takmalı ve her maske karakterin temel duygularını ifade etmelidir. Babanın maskesi pişmanlığı, Üvey Kız’ın maskesi intikamını, Annenin maskesi kederini ve Oğul'un maskesi küçümsemesini ifade etmelidir. Maskeli karakterler üstün bir bilince sahiptir ve aktörlerden daha yoğun, önemli ve sürekli karakterlerdir. Hayattan daha büyüktürler, ancak tam olarak çok yoğun ve dramatik oldukları için ölü olma deneyimine sahiptirler. Sanki sanat kaotik yaşamdan bir anlam yaratırlar ama aynı zamanda kendi hallerine de hapsolurlar. Buna karşılık aktörler aracısız ve kendiliğinden bir yaşamın niteliklerine sahiptir, ancak burada yaşamlarındaki halleriyle görünmezler. Her zaman bir canlandıracak metin arayışında olan ve ancak metinle canlanan tanımsız kişilerdir bu oyuncular. Tiyatroda bir gerçeklik bulma anı, iki kaotik özne grubunun karşılaştıkları tek andır. Pirandello'da sahne, farklı gerçekliklerin buluştuğu gaipten bir bölge olur. Sanatın insansızlaştırılması düşüncesinin başlangıcında tiyatro adına düşünce üretilen yer olarak görünür ve tam da bu esnada karakterle cebelleşmektedir (Pirandello, 2009).

Pirandello ve onun ironik insanlık anlayışı için tiyatro, insanın bilinciyle karakterleri kaderlerine hapsettikleri yerdir. Tiyatronun kendisi bir maskedir, maskelemedir. Birey hayatta kalmak için yapay bir düzen yaratırken, tiyatro kaotik bir gerçekliğe inşa edilmiş bir düzen uygulamaktadır. Varoluşsal bir ikilem için yaşam ve tiyatro çarpışması nasıl bir metaforsa, maske ve yüz de bu çarpışma rotasındaki başka metaforlardır. Maske ile yaşamak mümkün değildir, onsuz hayatta kalmak imkansızdır. Maske olumlu bir uyumlanmadır aslında. Çünkü kesin bir form ve içsel bir tutarlılık sağlar. Yaşamın karmaşasından yapay da olsa net bir desen oluşturur. Aynı zamanda da olumsuzdur. Çünkü insan yüzünün canlılığını bastırır ve kendini bilincin felç olma haline bağlar. Burada bir karşıtlar birliği elde etme imkânı yoktur. Maske ve yüz asla çözülemeyecek bir muhalefet halindedir. Karakter artık ontolojik olarak sorunlu hale gelmiştir. Marx için tam insan potansiyelinin bir maskeye indirgenmesi, kapitalizmin doğrudan bir sonucudur. Bireyin kendi toplumsal rolünün suni yapısını mutlak bir değer olarak yanlış algılamasıdır. Ancak Marx için maskenin hem başkalarına tepki olarak yaratılmış bir sosyal rol hem de kişisel bir sesi, bir kişiyi yansıtmak için seçilen bir araç olarak olumlayıcı bir tarafı da vardır (Urbanek, 1967, s. 536).

Brecht, yolsuzluğun, yoksulluğun, sefaletin ve bireyin acımasız sömürüsünün günlük fenomenler olduğu sınıflı toplumlarda, karakter analizinde Marx'ın takipçisidir. Maskeyi kişisel isteklerin ve onların arzularının gerçekleşmesine izin veren sosyal bir rol (persona) olarak kullanır. Öznenin sosyal yaşamı ile bütün bir kişiliğe ulaşması için bir gerekliliktir maske. Sezuan'ın İyi İnsanı adlı oyunda kadın fahişe Shen Te, maske ve kostüm kullanımı ile erkek kuzeni Shui Ta'ya dönüşerek gizlenir ya da büyür. Shen Te, başkalarına yardım etme arzusunda iyi kalpli, doğal, cömert, merhametli ve dürtüsel bir karakterdir. Aynı zamanda politik, sosyal ve duygusal olarak naif ve manipülasyonu kolay biridir. Shui Ta ise genç bir beyefendi görünümünde kurnaz, alaycı ve firsatçı bir karakterdir. Başkalarını sömürerek kendi sermayesini artırma yeteneğine doğuştan sahip; küçük bir tütün dükkanından tütün endüstrisi yaratmayı başaran bir kapitalisttir o. Her nasılsa sınıf sisteminin kazançları hakkında Shen Te'den daha büyük bir potansiyele sahiptir. Kadın özne, 'ego'sunu sosyal ve duygusal nedenlerle güçlendirilmiş bir çaresizlik eylemi olarak aşamalandırır. Maskeli yeni kişilik ona her iki rolde de hareket etme firsatı verir.

Çifte eyleminde karakter, fedakâr ve merhametli olmaya devam etmek için iki arzuyu birleştirir. Aynı zamanda çocuğunun geleceği için ekonomik varsayımlar yaratır, düşünür. Büyük duygusal çatışma anlarında, dişi, erkeksi maskeyi kırdığı için erkek kuzenin kimliği de tehdit edilir. İşte bu anlarda, yüzün/maskenin inşası bozulduğunda, Shui Ta'nın maskesini görüp Shen Te'nin sesini duyarız. Daha güçlü bir karakterin, kendinin daha savunmasız kısımlarını korumak için kontrolü ele aldığı çoklu kişilik bozukluğunda olduğu gibi, Shui Ta da Shen Te'yi kalıcı olarak yerinden etmekle tehdit eder. Sonunda Shen Te, sınıf sistemi ve ekonominin diyalektiği hakkında bilgi sahibi olmadan iyi olmanın, yarardan çok zarar getirdiğini anlar. İyiliğin toplum denilen somut alanın dışında var olamayacağının farkına varır. İyilik metafizik/manevi bir nitelik değildir, ancak sosyal boyutta anlam kazanır. Aslında her iki kimlik de gerçek benlik değildir. Shen Te, Shui Ta'nın kendisinin gerekli bir parçası olduğunu fark eder. Her ikisi de yüz ve maske arasındaki diyalektiğin yarattığı benliğin bileşenleridir. Eril ile dişi özne eşzamanlı olarak var olamadıklarından, eril maske mekansal boyuttaki kadınsı yüze karşıdır. Ancak birinin diğerini takip ettiği zamansal boyutta birbirlerini tamamlayabilirler.

Sosyal rol, eril maske, öznelliğin biçimsizliği ve kadınsı duyguların kaosuna geçerli sınırlar koyarak katı ve bütün bir kişilik dönüşümünü sağlayabilir. İyi kişi ancak bu haliyle toplumda işlev görebilir. Maske oyun boyunca bunu büyütme potansiyeli için çalışır. Brecht, yüzün ve maskenin öngörülen bir sentezine ulaşır ve sosyal rolün öze yeniden entegre edilmesine izin verebilecek bir umut elde ettiği bir diyalektik geliştirir. 
Zenciler: Bir Palyaço Gösterisi adlı oyununun prologunda Jean Genet, beyaz seyirciyi ya da onun bir kopyasını şart koşar.

Bir beyaz tarafından yazılan bu oyun, beyaz bir topluluğa oynanmalıdır. Olur da bir akşam zencilerin oluşturduğu bir seyirci topluluğu önünde oynanırsa, her temsile -erkek ya da kadın- bir beyaz davet edilmelidir. Gösteriyi düzenleyen bu davet/iyi şatafatla karş1/ama/1, tören e uygun giydirip, tercihen en öndeki koltukların ortasındaki yerine götürmelidir. Oyun, onun için oynanacaktır. Oyun sırasında, bir projektör bu sembolik beyazı sürekli aydınlatmalıdır. Hiçbir beyaz bu temsili izlemeyi kabul etmezse, o zaman oyuna gelirken girişte, zenci seyircilere beyaz maskeler dağıtılsın. Zenciler maske kabul etmezse o zaman manken kullanılsın (Genet, 2014, s. 13).

Sahnedeki aktörler, beyazlar ve siyahlar olarak iki gruba ayrılmış siyahlar olmalıdır. Beyaz Mahkeme Kraliçe, Vali ve mahkeme üyelerinden oluşur. Kraliçe, hüzünlü bir maske takar. Mahkeme üyelerinin maskeleri, beyaz sömürgeciliğin klişeleri olarak ihtişamlarını ifade eder. Siyah oyuncu kadrosu, bu oyunu beyaz mahkemenin beyaz maskelerinin arkasında açıkça görülebilen aktörlerin karanlığı ile oynamalıdır. Siyahları oynayan ikinci siyah aktör grubu, beyaz sosyal düzenin beklentilerinin onlara verdiği geleneksel roller olan siyah stereotipleri canlandıran siyah aktörlerdir. Ancak maskelerin kaldırılması oyunun belirtilen sonuna yol açmaz. Sonu oyunun başlangıcına benzer bir yapılandırmadır. $\mathrm{Bu}$ oyun, hem teatral hem de meta-teatral düzeyde, kültürel ve tarihsel olarak tanımlanmış, inşa edilmiş ve gerçekleştirilmiş bir süreç olarak ırksal kimliğin gerçekleştirilebilir performansına dair bir söylemdir. Bu ikili sistemde, siyahlar kendilerini beyaz olmaktan ayrı algılayamazlar, çünkü eylemleri tarihsel bir kolonileştirme ve ırkçılık sürecine tepki içerir. Beyaz otoriter sömürgeciliğin ve doğurduğu nefret iddiası taşır. Siyahların gösterisi, onların nefretinin, aptallığının, iğrençliğinin, suçluluğunun ve şiddetinin gösterisidir. İki kutup arasındaki tek olası ilişki, tiyatrodur. Tiyatro sahnesinde ve sadece maskelerini taktıklarında birbirlerine hitap edebilirler. Fanon, Siyah Deri Beyaz Maskeler çalışmasında sömürgeleştirilen topraklarda yaşayan siyahların paradoksundan söz eder. Siyah insan asla beyaz olamayacağını bilir ama ona benzeme arzusunu engelleyemez. Beyaza benzemek için elinden geleni yapar, beyaz maskelerini kuşanır. Bu esnada aslında farklı bir kişiliğe dönüştüğünden, siyahlar tarafından hemen anlaşılır. Beyaz karşısında aşağılık kompleksine kapılan siyahın böyle bir çabaya girmesinin, Batı merkezci bir kurgudan ibaret olan ben/öteki düalist kurgusu ve özne merkezli Aydınlanma düşüncesinin kolonyal söylemidir bu (Fanon, 2016, s. 25).

Tiyatro gerçeklikten daha gerçek, karakterler üstlendiklerinden daha gerçek, maskeler yüzden daha gerçek, illüzyon yansıttığı gerçekten daha gerçektir. Genet'in acımasız ritüellerinde, birey ancak toplumun inşasında rolünü bulduğunda kimliği doğrulanır. Maske yani persona: bir sosyal roldür ama bu maskenin arkasında kimse yoktur. Karakterlerin kendisi maskedir. Bu boş formlar, sadece ritüelin tekrarlayan gücünü yansitır. Sosyal ve ırksal rollerin sürekli güçlendirilmesi nedeniyle canlı olarak algılanır. Zaten kimlik bir performanstır ve sürekli tekrarlara dayanır. Karakter, ulaşılamaz, var olmayan bir orijinalin ertelenmesidir. İnsan yüzü stereotiplerin maskesi haline gelir ve maske altındaki hiçliği gizler. Genet'de maske, var olmayan bir benliğin, korkunç bir boşluğun işareti olarak insan deneyiminin ayrılmaz bir parçasıdır.

Brecht'in diyalektiğinin, Pirandello'nun metafiziğinin ve Genet'in ölüm ritüellerinin maske/yüz ikiliklerinde, tamamlanmış bir benliğin imkânsızlığına tanık oluruz. Ne de olsa modern özne ölüdür, ölü doğmuştur.

Benliğin asal krizi yüz/maske kutuplaşmasına dayanır. Batı düşüncesinde maske, her zaman muhalefet anlamına gelir. Maske her zaman öznelliğin nihai işaretinin aksine, eşsiz benlik, insan yüzü fikrinin son çaresidir. Maske, gerçek benlik yaratmanın imkânsızlığının bir işareti olsa da altta yatan bir melankoliye işaret eder. Pirandello ve Genet örneğinde olduğu gibi asla var olmayan için nostalji ya da gazaptır bu...

\section{Yeni Maske Olarak Antik Metamorfozun Dirilişi: Genet ve Müller’de Teatral Kullanımı}

Maske ile belirgin yakınlıkları olan başka bir kavram, metamorfoz kavramdır. Metamorfoz, görünümün veya maddenin dönüşümüdür. Bu radikal biçim değişikliği, kimlik birliği ve onun uzamsal-sürekliliği ile bir kopma içerebilir. Normal süreçte özne, fiziksel veya ruhsal dönüşümüne rağmen, metamorfoz süreci yoluyla kimliğini koruyabilir de. Metamorfoz, gerçek kapasitelerini ortaya çıkardığı, kavramlarımızı istikrarsızlaştırdığı ve alternatif dünyaların diğer olasılıklarını ortaya çıkardığı için kutsaldır. Kimlik kararsızdır, ancak metamorfoz onun hem kaybı hem de garantiye alınmış halidir. Metamorfoz ânı, hem kendinden önce hem de sonraki anları içine alır. Paradoksal olarak, kimlik istikrarsızlaşırken bile kendisinin hayatta kalmasını sağlar.

Ĕ̆er özne, temel olarak kimlik paradoksları arasında sıkışmış şizoid bir özne ise, metamorfoz bir çıış yolu sunar. Metamorfoz, insanın hayvansal ve ilahi kaynağını aşmaya yönelik hayali yeteneği ile insanın cinsiyet, zaman, mekân boyutunu diğer alanlarına yeniden bağlanır. Ve maske; metamorfozun en güçlü işareti haline gelir, çünkü onu burada ve şimdi görsel bir deneyime dönüştürür.

Antik çağda popüler olan metamorfoz kavramı, Avrupa tiyatrosunun başlangıcından beri açık bir kutsallık özelliği olarak ortaya çıkmıştır. Aiskhylos'un Orestes Üçlemesi'nin sonunda İntikam korosu (Erinysler), dua eden ruhlara, hayırlı tanrıçalara (Euminidlere) dönüşür. Uzun bir sessizlik döneminden sonra metamorfoz tekrar cazip hale gelir 
ve yirminci yüzyıldaki tiyatro sahnesine yeniden girer. Yukio Mishima'nın No oyunlarından birinde, Sotoba Comachi, 99 yaşındaki homoseksüel karakter, 80 yıl öncesine dayanan yaş ve uzamsal birliği aşarak kendini on dokuz yaşındaki kıza dönüştürür.

Kafka’nın Samsa'sı arketipli Ionesco'nun Gergedan oyununda Berenger gergedanlaşarak başkalaşmayı arzular ancak bunu bir türlü gerçek kılamaz. Bu huzursuz bir süreci imler.

Sarah Kane'ün Cleansed oyununun sonunda Grace karakteri, ölen kardeşi Graham'a benzer ve ona ait sesleri çıkarır. O da başkalaşmıştır.

Genet'in hizmet eden karakterleri başkalaşır; Solange Claire, Claire Solange, ikisi de Saygın Bayan olur. Tiyatro buna rol yapma dese de kökende av ritüellerine dek gideceğimiz bir başkalaşım isteği olduğu yadsınamaz.

Heiner Müller'in Laclos'un Tehlikeli İlişkiler romanının postmodern yorumu olan Dörtlü'sünde (Quartet) Valmont Merteuil, Merteuil de Valmont olmuştur. Hatta karakterler o kadar çok başkalaşırlar ki, Müller'in belirsizliğinde bir dizi metamorfoz içeren bir oyun olarak yorumlanabilir. Fransız Devrimi'nden önce bir salon ve Üçüncü Dünya Savaşı'ndan sonra bir sığınak olarak tanımlanan zaman/mekân sürekliliğinde Merteuil'in bakire yeğeni olan Solange ve yargıcın sadık eşi Madame de Tourvel de vardır sahnede, onların ses, yüz ve bedenlerinde. Cinsellik, şehvet, arzu, ahlak ve duygular, cinsiyetlerin ebedi savaşında egemenlik ve boyun eğme araçlarından başka bir şey değildir. Onların güç oyunları, ölüme yol açan arzuyu ve rekabeti birleştiren, ritüel yasasına dayalı bir modeldir. Metnin belirsizliği içinde diğer karakterin replikleri, kimlik değişiklikleri içinde bir maskeli balo veya gerçek bir metamorfoz olup olmadığını bir türlü tanımlayamayız. Merteuil, Valmont olur ve orada bulunmayan Tourvel ve Solange'a hitap eden bir monolog söyler. Merteuil/Valmont'a cevap veren Valmont/Tourvel olur ve sonunda intihar eder. Ölüm anında ise Merteuil tarafından zehirlenen Valmont'a geri döner. Ölüm, Merteuil'in son repliğinde "Artık başbaşayız, kanser sevgilim” cümlesiyle olması beklenen şeyin kendisidir. Bu kıyamet sonrası manzarasında, erkeğin intikam alan kadının elinden gelen ölümü ile oyun sona erer. Oyuna maske yoluyla gerçek metamorfozu da eklersek, başka bir boyut daha geliştirilmiştir. İki Valmont'un sahnesinde iki kez eşzamanlı olarak var olunmaktadır. Biri Valmont'un yüzü, vücudu/sesi ve Tourvel'in sözleri ve diğeri Valmont'un maskesi, Valmont'un metni ve gövdesi/Merteuil'in sesi. Bu şekilde, öznenin beden, ses ve metnin kurucu unsurlarına ayrışması söz konusudur. "Şeytanın pek çok kılığı vardır. Yeni bir maske mi Valmont (Müller, 2008, s. 207)” diyen Valmont, başkalaşımını sesiyle, sözüyle, maskesiyle müjdeler.

"Aynadan bakan hep ötekidir. Yabancı bedenlerin altını üstüne getirirken onu ararız kendimizden uzakta. Belki de ne o, ne de öteki vardır, yem için gaklayan ruhumuzdaki hiçlik vardır yalnızca” (Müller, 2008, s. 200).

Metamorfoz, Müller'in kullanımıyla maskenin varlığını çağdaş sahnede gerçekleştirmenin bir yolu olarak görülebilir.

\section{Sonuc}

Özne artık tanımlanabilirlik, esaslılık, süreklilik veya aracısız ve kendiliğinden bir yaşam hissi ile ayakta duran bir ontolojik temel üzerinde bir öz değildir. Tarihi, sosyal, ırksal, etnik ve toplumsal cinsiyet yapısı haline gelmiştir. Özne, performans yoluyla bir kimlik benzerliği elde edilen bir tekrarlama alanıdır (Butler, 2007). Süreç, bu tür performanslarla oluşturulur ve istikrarlı bir kimlik olarak ortaya çıkması konusu bizi Genet'nin ritüel tiyatrosunu da hatırlatan ritüelin yasalaşması ilkesine götürür.

Genet'nin karakterleri rol yapar. Üstelik bu karakterlerin sistemle ve sistemi oluşturan tüm arketiplerle derdi vardır. Onları temsil yoluyla komik bir büyüteç altına alır ve aynada görünme umudu olanı defalarca kırarak seyirciyi farklı görüntüler arasında bir anlam arayışına sevk eder. Kimliği Genet'nin oyun kişisinde sabitleme hayali yararsız bir çaba haline gelir. Av ritüellerindeki güçlenme amaçlı başkalaşımı kendi ritüel tiyatrosuna taşıyarak antik metamorfozu diriltir. Hizmetçiler, Balkon, Paravanlar oyunlarında soyut veya somut bir mask yoluyla gerçekleştirdiği bu metamorfoz onun tekniğinde ve denemelerinde öyle bir hale dönüşür ki Zenciler'de seyirciyi de başkalaştırmak ister ve onlardan maske takmalarını talep eder. Tiyatronun da alanını genişletmiş olur.

Pirandello maske ve yüz kavramını modern psikolojiden ödünç alarak sahne üzerinde sorgulayan oyun yazarlarından biri olarak yaratma kavramını teatralleştirir. Diderot'nun yaratıcıyla konuşan Kaderci Jacques ve Efendisi ilk romanında olduğu gibi Pirandello da sahnede yazarını arayan kurgu karakterlerle modernist yazarın kurgusunu katmanlaştırır. Benliği performatif bir süreç haline getirir. Maske sosyal bir temsile denk düşer. İnsan biri ve binlercesi olabilir. Ondan talep edilen budur ve sahnede de tıpkı yazarını arayan altı kişiye fazla odaklandığımızda gözden kaçırdığımız oyuncular gibi kimliği, kendi olmanın ötesinde yüzlerce rol beklemektedir.

Modernist öznenin postyapısalcı öznellik teorilerinin çelişkili özelliklerini ele almaya çalışmak, birleşik bir kavramdan uzaklaşarak çok merkezsiz ve değişebilir bir benliğe doğru bir hareketi savunmuştur. Kimlik alanını kalıcı olarak sorunlu hale getirmek için çokluk, bir strateji haline gelmiştir. 
Müller postmodernist bir yazar olarak karşı gerçekçilerin ve absürdistlerin kimliği çoğaltma ve bölme stratejisini kullanır. Hamlet Makinesi'nde yine bir oyuncuyu kendi evreni içinde politik, hümanist, estetik, sosyolojik, psikolojik açılımlarıyla baş başa bırakır. Onu onlarcaya çoğaltır ve böler. Benzer bir yapıyı Dörtlü'de kullanır ve bizi bildik bir romanın içindeki karakterleri yani halihazırda bir eser içine firlatılmış karakterleri metamorfoz yoluyla çoklu hale getirir. Modernist yazarlarda bir zamanlar maskenin çok belirli biçimde yaptığını artık metamorfoz yapmaktadır. Tek bir belirleyicilik esasında değil stratejik olarak çoklu ve belirsiz bir başkalaşım arzusuyla... 'İronik benlik' karakter yaratmada oyun yazarının güçlü bir belirleyicisi haline gelir.

Richard Rorty, ironiyi, insanın "kendisini tanımladığı sıfatların sürekli değişmesi, ayrıca kullandığı kelimelerin ve dolayısıyla benliğinin olumsal ve kırılgan olduğunun her zaman farkında olması nedeniyle kendi kendini ciddiye alamaması" olarak tanımlar. Rorty'nin bahsettiği türden bir ironik karakter, modern dünyada kişinin kendisine zarar verir; hiçbir şeyin sabit olmadığına inanan insan, bir süre sonra, "ben pek de gerçek değilim, benim ihtiyaçlarımın da temeli yok" noktasına gelir. Kişinin değerini takdir edecek bir insan, bir otorite yoktur artık (Sennett, 2008, s. 122). Kaygan bir benlik ve sürekli oluş halindeki bir kolaj (Sennett, 2008, s. 140) yeni kapital düzende benliği sürekli değişken ve arayış içinde kılmaktadır. Bu da tek bir uzmanlık ve tek bir işle hayatını tamamlayanların devrinin bittiğini gösterir. İşin sosyal maskeler edinmedeki rolü hatırlandığında sabiti olamayan insanın maskelerinin ne denli çoğaldığı ve kimliğin daha da belirsizleştiği ortaya çıkacaktır. Sabitlerinden vazgeçme eğilimi içindeki insan artık sürekli başkalaşmaktadır. Eşi, işi, evi, yüzü, coğrafyası, değer sistemi, görme biçimi ve diğerlerinin kendisini görme biçimleri aynı olamaz. Zaman algısı kuantum teorisiyle farklılaşan ve geçmiş ve geleceği hayal, şimdiyi ise belirsiz görme eğilimi karakteri sabitleyemeyecek unsurlardan biri olur.

Elbette tüm bunlar yirminci yüzyılın tarihsel travmasının estetiğidir. Aydınlanma rasyonalitesinin ve bütünleşik benliğin sıfır noktası, 1. ve 2. Dünya Savaşı, Auschwitz ve Hiroşima, 9/11 nefret teolojileri, gezegenin devam eden ekolojik yıkımı tarafından tanımlanan zaman/mekân... Küresel kapitalizm ve küresel çeşitliliğe maruz kalınması, teknolojik gelişmeler ve kültürler ile ülkeler arasındaki artan temas ile postmodernite... Rasyonellik, insanlık ve öznellik kavramları bir daha asla aynı olamayacaktır.

Derin hipnozda veya ölümün eşiğinde gibidir insan. Ne sarılacak bir geçmişi ne de umutlu bir geleceği vardır. Hepsi şimdi, burada ve çoklu bir zamanda, değişken bir benlikle yaşanmaktadır. Geçmiş, gelecek ve şimdi... O yüzden de maske ve metamorfoz formu tam da şimdide, benliği değişkenliği içinde sabitlemeye çalışır. Benlik ise her defasında kayıp gider, bir türlü tutulamaz... Ne hayatta ne de sahnede...

Sonuç olarak; arayışına maskeyle başlayıp onun yetersizliği durumunda antik metamorfozun yeniden keşfiyle süren modern oyun yazarlığında karakter yaratımı, kaçınılmaz olarak çokluk stratejisine tabi tutulmuştur. Pirandello'nun psikolojik rölativizm etkisinde ve Genet'nin aynalar labirentinde başlayan serüveni Müller'in sadece psikolojik değil sosyolojik, politik ve hatta zaman/mekân rölativizmiyle devam etmektedir. Metamorfoz bir araç olarak modern sonrası tiyatroda da yerini korumaktadır.

\section{Kaynakça}

Akın, B. A. (2017). Genet'nin ezilenleri ve hainleri. İstanbul: Mitos Boyut Yayınları.

Aydoğdu, H. (2004). Modern kimlikte öznenin ölümü. Kazım Karabekir Eğitim Fakültesi Dergisi, 0(10), 115-147. Erişim adresi: https://dergipark.org.tr/tr/download/article-file/31406

Butler, J. (2007). Taklit ve toplumsal cinsiyete karşı durma (O. Akınhay, Çev.). İstanbul: Agora Kitaplığı.

Çehov, A. (1995). Bütün oyunları II (A. Behramoğlu, Çev.). İstanbul: Remzi Kitabevi.

Fanon, F. (2016). Siyah deri beyaz maskeler (C. Koytak, Çev.). İstanbul: Encore Yayınları.

Fuchs, E. (2003). Karakterin ölümü (B. Güçbilmez, Çev.). Ankara: Dost Yayınları.

Genet, J. (1991). Paravanlar (S. Dolanoğlu, Çev.). İstanbul: Remzi Kitabevi.

Genet, J. (2000). Hizmetçiler (S. Birsel, Çev.). İstanbul: Nisan Yayınları.

Genet, J. (2014). Zenciler (2. Baskı) (N. Başer, Çev.). İstanbul: Ayrıntı Yayınları.

Horkheimer, M., \& Adorno, T. W. (2010). Aydınlanmanın diyalektiği (N. Ülner \& E. Karadoğan, Çev.). İstanbul: Kabalcı Yayınları.

Jacobi, J. (2002). C. G. Jung Psikolojisi (M. Arap, Çev.). İstanbul: Barış İlhan Yayınevi.

Kahraman, Y. (2018). Kurucu öğe olarak modern özne anlayışının teşekkülü. Kaygl, 31, 128- 144. doi: 10.20981/kaygi.474645

Kurun, İ. (2018). Karl Popper'ın idealizm eleştirisi. Beytulhikme: An international journal of philosophy, 8(1), 273-301. Erişim adresi: https://philarchive.org/archive/KURKPC 
Müller, H. (2008). Hamlet makinesi (Z. A. Yılmazer, Çev.). İstanbul: De ki Yayınları.

Nesari, A.J., Shahraz, S., Filinezhad, N., \& Nesarid, S. J. (2011). A study of the lack of identity in Luigi Pirandello's six characters in search of an author and Henry IV. Procedia-Social and Behavioral Sciences, 28, 896-899.

Pirandello, L. (2009). Toplu oyunları 1 (G. Çapan, N. Adabağ \& H. Aygen, Çev.). İstanbul: Mitos Boyut Yayınları.

Pirandello, L. (2015). Biri, hiçbiri, binlercesi (B. Göker \& N. Birgen, Çev.). İstanbul: Aylak Adam Yayınları.

Sennett, R. (2008). Karakter aşınması (B. Yıldırım, Çev.). İstanbul: Ayrıntı Yayınları.

Urbanek, E. (1967). Roles, masks and a characters: a contribution to Marx's idea of social role. In social Research (34(3), p. 529-562). Baltimore, Maryland: Johns Hopkins University Press. Erișim adresi: https://www.jstor.org/stable/40969892?seq=1

Zohar, D. (2019), Kuantum benlik (S. Kervanoğlu, Çev.). İstanbul: Ayrıntı Yayınları. 